320

ग) 14164

\title{
DESTRUCTIVE EVALUATION OF IRRADIATED ZIRCALOY SHEATHING \\ zy
}

M.R. LOUTHAN, Jr.

DP-888

बIUPOND

Savannah River Laboratory

Aiken, South Carolina 


\section{DISCLAIMER}

This report was prepared as an account of work sponsored by an agency of the United States Government. Neither the United States Government nor any agency Thereof, nor any of their employees, makes any warranty, express or implied, or assumes any legal liability or responsibility for the accuracy, completeness, or usefulness of any information, apparatus, product, or process disclosed, or represents that its use would not infringe privately owned rights. Reference herein to any specific commercial product, process, or service by trade name, trademark, manufacturer, or otherwise does not necessarily constitute or imply its endorsement, recommendation, or favoring by the United States Government or any agency thereof. The views and opinions of authors expressed herein do not necessarily state or reflect those of the United States Government or any agency thereof. 


\section{DISCLAIMER}

Portions of this document may be illegible in electronic image products. Images are produced from the best available original document. 
This report was prepared as an account of Government sponsored work. Neither the United States, nor the Commission, nor any person acting on behalf of the Commission:

A. Makes any warranty or representation, expressed or implied, with respect to the accuracy, completeness, or usefulness of the information contained in this report, or that the use of any information, apparatus, method, or process disclosed in this report may not infringe privately owned rights; or

B. Assumes any liabilities with respect to the use of, or for damages resulting from the use of any information, apparatus, method, or process disclosed in this report.

As used in the above, "person acting on behalf of the Commission" Includes any employee or contractor of the Commission, or employee of such contractor, to the extent that such employee or contractor of the Comission, or employee of such contractor preparcs, disseminates, or provides access to, any information pursuant to his cmployment or contract with the Commission, or his employment. with such contractor.

Printed in USA. Price $\$ 0.50$

Avallable from the Of'l'ice of' 'l'echnical services

U. S. Department of Commerce

Washington 25, D. C. 


\section{DESTRUCTIVE EVALUATION OF IRRADIATED ZIRCALOY SHEATHING}

by

McIntyre R. Louthan, Jr.

Work done by

A. S. Ferrara, M. R. Louthan, Jr.,

W. G. Holmes, and R. D. Kelsch

Approved by

P. H. Permar, Research Manager

Pile Materials Division

May 1964

E. I. DU PONT DE NEMOURS \& COMPANY

EXPLOSIVES DEPARTMENT - ATOMIC ENERGY DIVISION

TECHNICAL DIVISION - SAVANNAH RIVER LABORATORY

AIKEN, SOUTH CAROLINA

CONTRACT AT (07.2) - 1 WITH THE

UNITED STATES ATOMIC ENERGY COMMISSION 


\begin{abstract}
The effect of irradiation on the ability of Zircaloy-sheathed oxide fuel tubes to withstand sheath strains during reactor service was determined by mechanical burst, weld-shear; and bend tests. The ductility of the sheath was not affected by irradiation exposures up to approximately $10^{20}$ fast nvt, and increases in the weldshear strength were observed.
\end{abstract}




\section{CONTENTS}

Page

Introduction ................. . . 4 4

Summary . . . . . . . . . . . . . . 5

Discussion .................. . . 5

Description of Elements and Irradiations . . . . 5 .

Description of Sheath . . . . . . . . . 5

Element Design and Fabrication ........ 5

Irradiation Conditions . . . . . . . . 6

Experimental Procedures . . . . . . . . . . 8

Experimental Results. . . . . . . . . . . 10

Preirradiation Tensile Tests. . . . . . . 10

Weld-Shear 'liests . . . . . . . . . . . 11

Mechanical Burst Tests . . . . . . . . 12

Conclusions. . . . . . . . . . . . . . 14

References ................... 15

\section{List of Tables and Figures}

Table

I Fabrication Details of Elements for the SPRO

Assemblies. . . . . . . . . . 6

II Room Temperature Tensile Properties of Sheathing 10

III Weld-Shear Strengths of Inner Sheath Welds • . 1.1.

IV Mechanical Burst Tests of Sheathing . . . . 13

Figure

1 Dimensions of Fuel Elements for the SPRO-5, -12, and -13 Assemblies . . . . . . . . 7

2 Weld Designs for the SPRO-5, -12 , and -13 Elements . . . . . . . . . . . 7

3 Apparatus for Weld-Shear Tests . . . . . 8

4 Apparatus for Mechanical Burst Tests . . . 9 


\section{DESTRUCTIVE EVALUATION OF IRRADIATED ZIRCALOY SHEATHING}

\section{INTRODUCTION}

Thin-walled Zircaloy tubing is used at the Savannah River Laboratory as sheath material for tubular oxide fuel elements fabricated by vibratory and swage compaction. During irradiation the sheath must withstand, without fallure, strains produced by internal gas pressure and by differential thermal expansion between the oxide core and the sheath. It is therefore desirable to know the effect of irradiation on the ability of the sheath to withstand these strains. This report describes tests made to determine the effects of irradiation on the strength and ductility of the sheathing from experimental Zircaloysheathed oxide fuel elements irradiated in the SRP production reactors in 1960 through 1962.

Early irradiation failures by brittle fracture of the outer sheath af'ter exposures of about $10^{20}$ fast nvt were attributed to local hydriding of the sheaths and massive deposits of hydride at the sheath-core interface. (1) Subsequent improvements in fabrication eliminated the hydriding problem; however, some concern remained as to the effect of irradiation per se on the ductility of the sheathing.

A number of investigations ${ }^{(2-5)}$ of the mechanical. properties of Zircaloy have been made: Pankaskie and Knecht ${ }^{(2)}$ determined the properties of thin-walled tubing for the Plutonium Recycle Test Reactor; Rittenhouse and Picklesimer ${ }^{(3)}$ measured the tensile properties and strain behavior of Zircaloy plates with differing preferred orientations; Burton ${ }^{(4)}$ determined the ef'fect of hydrogen on the tensile properties of Zircaloy-2; and Green, White, and Isserow ${ }^{(5)}$ studied the factors affecting the ductility of tubular Zircaloy-clad fuel elements. Other investigators determined the effect of irradiation on the tensile properties of Zircaloy and indicated that some irradiation embrittlement did occur. $(6,7)$

However, studies by Sturcken and Duke ${ }^{(8)}$ and Rittenhouse and Picklesimer ${ }^{(3)}$ have shown that the strain behavior of Zircaloy is markedly affected by its preferred orientation (texture) and that the texture is controlled by fabrication techniques. These studies indicated that information previously developed on tubing of different sizes, manufactured by different techniques, and fabricated into fuel elements by different processes will not necessarily furnish the data required for the work at the 
Savannah River Laboratory. Therefore, the effect of irradiation on the mechanical stability of the zircaloy sheath used at.SRL was investigated.

\section{SUMMARY}

The effect of Irradiation on the ability of zircaloysheathed oxide fuel tubes to withstand sheath strains produced during reactor service was determined by mechanical burst, weld-shear, and bend tests. The ductility of the sheath was not affected by irradiation exposures up to approximately $10^{20}$ fast nvt and increases in the weld-shear strength were observed.

\section{DISCUSSION}

\section{DESCRIPTION OF ELEMENTS AND IRRADIATIONS}

\section{Description of Sheath}

The Zircaloy tubing used as sheath material was commercially fabricated by extrusion of copper-jacketed billets at $788^{\circ} \mathrm{C}$. The tubing was drawn to size at room temperature with intermediate anneals at $650^{\circ} \mathrm{C}$. After the final drawing to a wall thickness of about $30 \mathrm{mils}$, the tubing was etched in a $\mathrm{HNO}_{3}-\mathrm{HF}$ mixture, vacuum annealed at $650^{\circ} \mathrm{C}$, and stretch straightened. Standard Zircaloy-2 tubing was used for the SPRO-5 assembly and low-nickel Zircaloy-2 for the SPRO-12 and -13 assemblies. Nominal compositions of these alloys are given in the following table.

\section{Compositions of Zircaloy-2, wt \%}

\begin{tabular}{lccccc}
\multicolumn{1}{c}{ Grade } & Sn & $\underline{F e}$ & $\underline{\mathrm{Cr}}$ & $\underline{\mathrm{N}}$ & $\underline{\mathrm{Zr}}$ \\
Standard & $1.2-1.7$ & $0.07-0.20$ & $0.05-0.15$ & $0.03-0.08$ & $\mathrm{Bal}$ \\
Low-N1 & $1.2-1.7$ & $0.18-0.29$ & $0.07-0.13$ & $0.007-\mathrm{Max}$ & $\mathrm{Bal}$
\end{tabular}

\section{Element Design and Fabrication}

The tubular elements were $1-1 / 2$ to 2 feet long, with outside diameters of approximately $2-1 / 4$ inches and inside diameters of approximately $1-1 / 2$ inches. The irradiation assemblies corisisted of five or six tubes, stacked vertically in ribbed aluminum housing tubes. The elements were fabricated 
by vibratory compaction or by vibratory compaction followed by cold swaging as described in DP-515, -665, and $-715^{(10,11,12)}$. Specific details for individual assemblies are given in Table I and Figure 1 .

TABLE I

Fabrication Details of Elements for the SPRO Assemblies

\begin{tabular}{|c|c|c|c|}
\hline \multirow[t]{2}{*}{$\because$} & \multirow[b]{2}{*}{ Assembly No. } & \multicolumn{2}{|c|}{ Fabrication Technique } \\
\hline & & Vibratory(a) & Swaged $(\mathrm{b})$ \\
\hline No. of tubes per assembly & $\mid \begin{array}{r}5 \\
12 \\
13\end{array}$ & $\begin{array}{l}0 \\
3 \\
2\end{array}$ & $\begin{array}{l}6 \\
3 \\
3\end{array}$ \\
\hline $\begin{array}{l}\text { Oxide density after vibratory } \\
\text { compaction, } \mathscr{\phi}^{(c)}\end{array}$ & $\left\{\begin{array}{r}5 \\
12 \\
13\end{array}\right.$ & $\begin{array}{l}- \\
82 \\
161\end{array}$ & $\begin{array}{l}72 \\
80 \\
84\end{array}$ \\
\hline $\begin{array}{l}\text { Oxide density after swaging, } \\
\mathscr{g}_{0}^{(c)}\end{array}$ & $\left\{\begin{array}{r}5 \\
12 \\
13\end{array}\right.$ & $\begin{array}{l}- \\
-\end{array}$ & $\begin{array}{l}91 \\
90 \\
92\end{array}$ \\
\hline No. of swaging passes & $\mid \begin{array}{r}5 \\
12 \\
13\end{array}$ & - & $\begin{array}{l}7 \\
2 \\
2\end{array}$ \\
\hline $\begin{array}{l}\text { Reduction in cross-sectional } \\
\text { area of inner sheath, } \%\end{array}$ & $\mid \begin{array}{r}5 \\
12 \\
13\end{array}$ & $\begin{array}{l}- \\
0 \\
0\end{array}$ & $\begin{array}{r}16 \\
9 \\
9\end{array}$ \\
\hline $\begin{array}{l}\text { Reduction in cross-sectional } \\
\text { area of outer sheath, } \phi\end{array}$ & $\mid \begin{array}{r}5 \\
12 \\
13\end{array}$ & $\begin{array}{l}- \\
0 \\
0\end{array}$ & $\begin{array}{r}14 \\
7 \\
7\end{array}$ \\
\hline
\end{tabular}

(a) V1bratory compaction alone.

(b) Vibratory compaction followed by cold swaging.

(c) Oxide densities are listed as o theoretical.

The end plug design for the SPRO-5 assembly differed from the plug design for the SPRO-12 and -13 assemblies (Figure 2). The weld configuration was redesigned for the latter two assemblies to obtain greater assurance of satisfactory closures.

The end plugs for the SPRO-5 assembIy were welded under conditions that led to oxyger and nitrogen contamination of the weld. This condition was remedied for the SPRO-12 and -13 assemblies by welding in a dry box to provide better control of the atmosphere; both of these assemblies were welded under similar conditions except that the SPRO-13 welds were made at higher powers to increase weld penetration.

\section{Irradiation Conditions}

The assemblies were irradiated in a Savannah River Plant (SRP) reactor to exposures up to approximately $10^{20}$ fast nvt at coolant temperatures below $100^{\circ} \mathrm{C}$. 

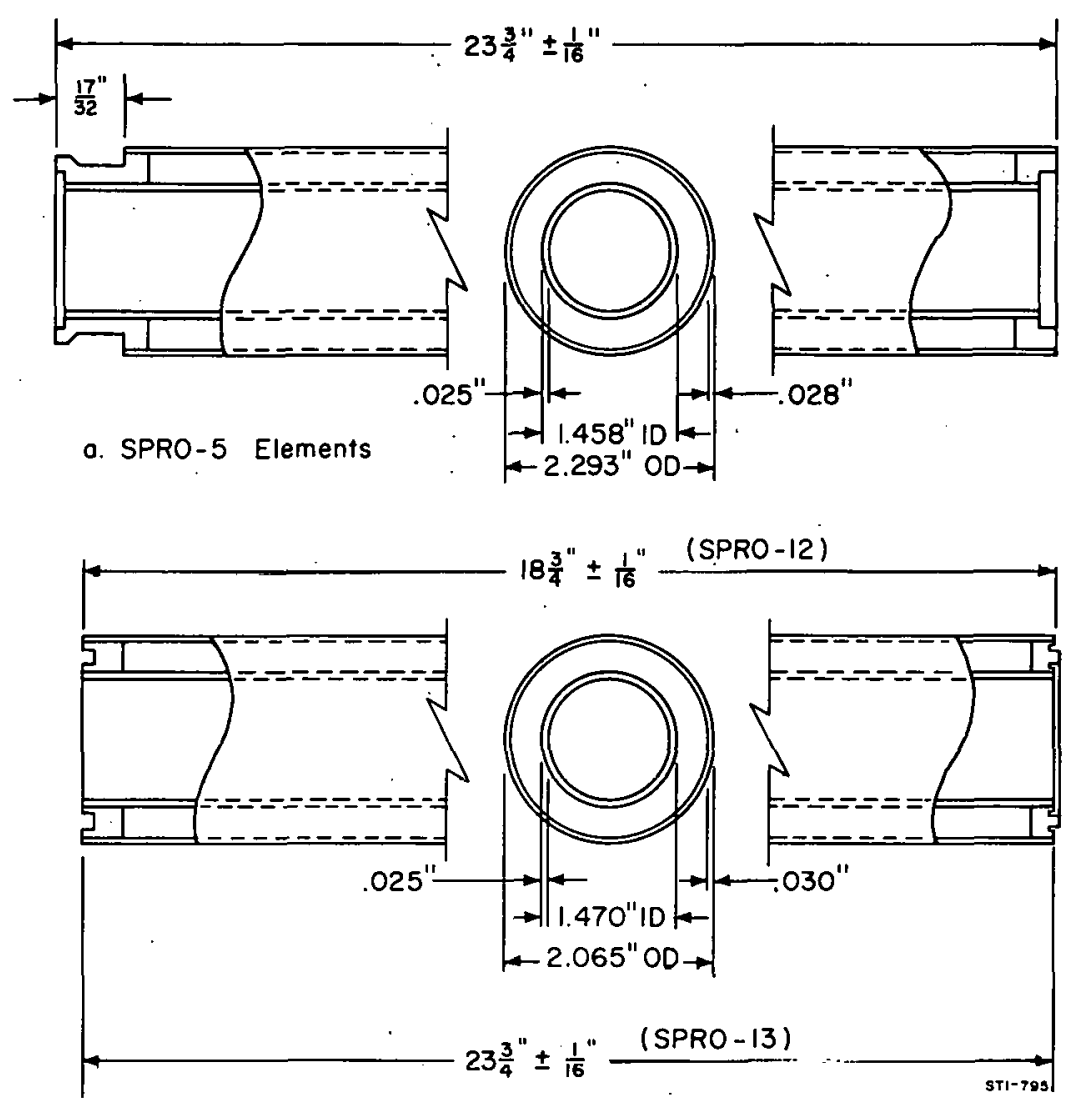

b. SPRO-12 and - 13 Elements

FIG. I DIMENSIONS OF FUEL ELEMENTS FOR THE SPRO- $5,-12$, AND -13 ASSEMBLIES

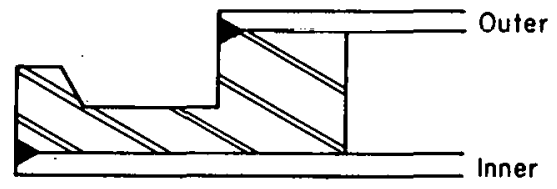

Front End Plug

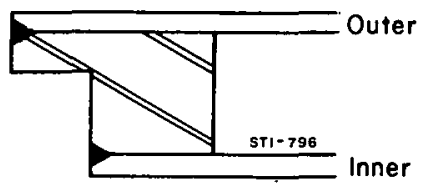

Rear End Plug

o. SPRO-5 Elements

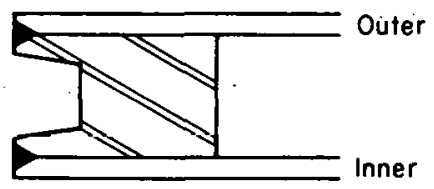

Front End Plug

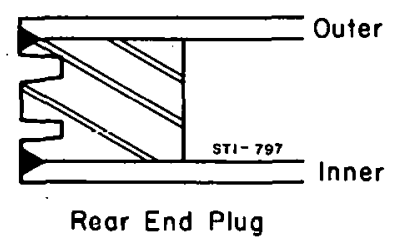

b. SPRO -12 and -13 Elements

FIG. 2 WELD DESIGNS FOR THE SPRO-5,-12, AND -13 ELEMENTS 


\section{EXPERIMENTAL PROCEDURES}

It was impractical to machine tensile specimens from the irradiated sheaths. Therefore, standard tensile tests were made only on unirradiated sheaths, and weld-shear, mechanical burst, and bend tests were performed directly on irradiated elements, and on companion unirradiated elements for comparison.

The tensile tests on the unirradiated sheaths were performed at strain rates between 0.02 and $0.04 \mathrm{inch} / \mathrm{inch} / \mathrm{minute}$. Load-elongation data were recorded by an autographic recorder with a microformer-type extensometer. The ultimate tensile strength and the $0.2 \%$ offset yield strength were estimated from the load-elongation curves and pretest specimen measurements. The elongation and reduction in area were determined from measurements made directly on the samples.

Weld-shear tests were made by rupturing the fusion weld at the end plugs by pulling the inner sheath while restraining the end plug. The apparatus l'or the weld-shear test is ahown schematically in Figure 3 . The outer sheath was removed from the test section after the oxide core had been pickled from the tube in a nitric acid bath. The weld-shear strength was expressed as load required to rupture the weld.

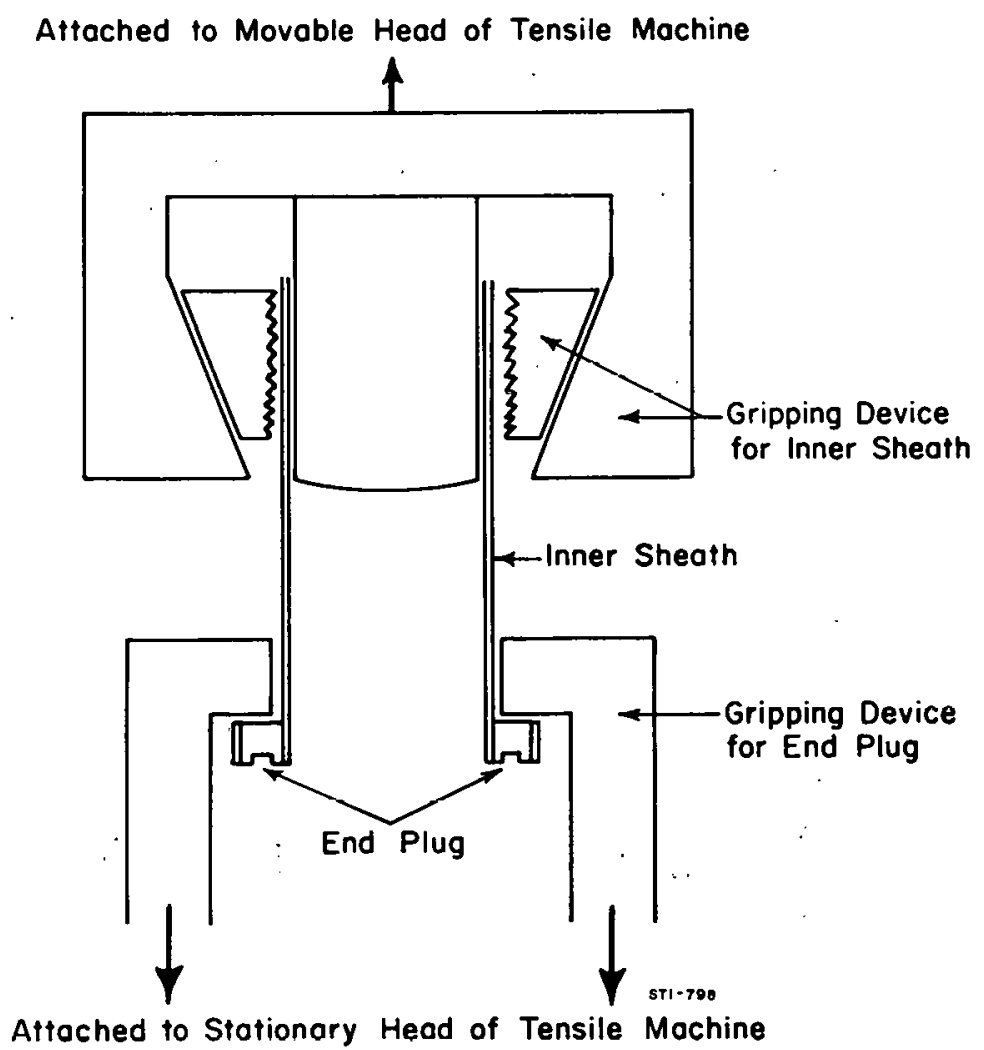

FIG. 3 APPARATUS FOR WELD-SHEAR TESTS 
Mechanical burst tests were performed on ring sections of the outer sheath by forcing a tapered steel mandrel through an aluminum liner contained in the sheath (Figure 4). The elongations, both maximum and uniform, were determined by measuring the diametral increases on the aluminum liner after sheath fracture. The diameter of the liner was measured every 30 degrees around the circumference. The maximum diametral increase was reported as maximum elongation, and the minimum diametral increase was reported as minimum elongation. To determine the accuracy of this type of measurement, minimum and maximum elongations on several specimens were determined from increases in the grid spacing of $1 / 4-$ inch grid lines scribed on the aluminum liner and on the test specimen. The elongations obtalned from all three measurements were quite similar; therefore, diametral measurements, being the easiest to obtain, were used.

Mechanical bend tests were performed on longitudinal strips to determine the minimum radius of bend that a specimen could accommodate without rupture. It had been expected that the preirradiation strips could be bont double without failure and only the irradiated strips could be tested to fracture. However, both types readily accommodated a radius of curvature of $1 / 8$ inch, the limil of the test equipment, without fracture.

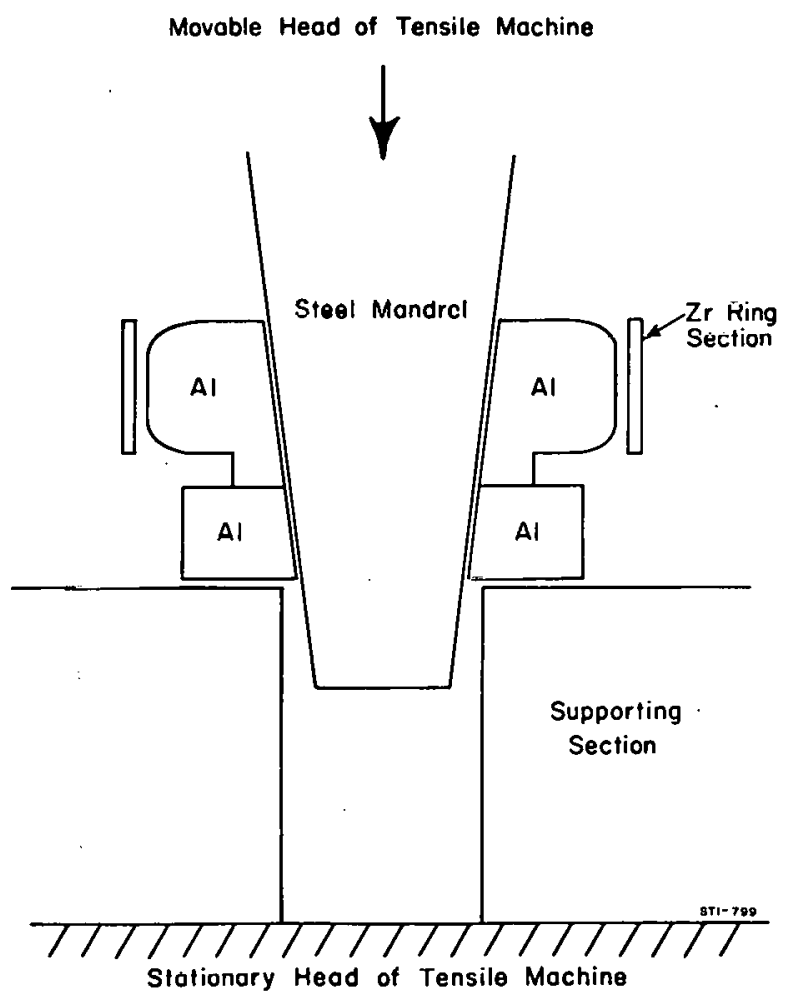

FIG. 4 APPARATUS FOR MECHANICAL BURST TESTS 


\section{EXPERIMENTAL RESULTS}

\section{Preirradiation Tensile Tests}

The room temperature tensile properties of the asreceived tubing (Table II) were not affected by vibratory compaction; however, swage compaction increased the sheath strength and decreased its ductility.

TABLE II

Room Temperature Tensile Propert1es of Un1rradiated Sheathing (a)

\begin{tabular}{|c|c|c|c|c|c|c|}
\hline $\begin{array}{c}\text { Assembly } \\
\text { Number } \\
\end{array}$ & $\begin{array}{l}\text { Type and Condition } \\
\text { of Sheathing } \\
\end{array}$ & Orientation & $\begin{array}{c}0.2 \% \text { y1eld } \\
\text { strength, } \\
\text { ps1 } \\
\end{array}$ & $\begin{array}{l}\text { Ultimate } \\
\text { Tensile } \\
\text { Strength, } \\
\quad \text { psi } \\
\end{array}$ & $\begin{array}{c}\text { Elongation, } \\
\frac{8}{8}\end{array}$ & $\begin{array}{l}\text { Reduction } \\
\text { in Area, } \\
\end{array}$ \\
\hline \multirow[t]{4}{*}{$\operatorname{sPRO-5}(b)$} & $\begin{array}{l}\text { Outer } \\
\text { As-recelved }\end{array}$ & $\begin{array}{l}\text { lotig. } \\
\text { C1rcum. }\end{array}$ & $\begin{array}{l}61,000 \\
80,000\end{array}$ & $\begin{array}{l}87,000 \\
89,000\end{array}$ & $\begin{array}{l}16 \\
12\end{array}$ & $\begin{array}{l}43 \\
56\end{array}$ \\
\hline & $\begin{array}{l}\text { Outer } \\
\text { Swaged }\end{array}$ & $\begin{array}{l}\text { Long. } \\
\text { C1rcum. }\end{array}$ & $\begin{array}{l}91,000 \\
78,000\end{array}$ & $\begin{array}{r}95,000 \\
102,000\end{array}$ & $\begin{array}{l}7 \\
6\end{array}$ & $\begin{array}{l}39 \\
39\end{array}$ \\
\hline & $\begin{array}{l}\text { Inner } \\
\text { As-recelved }\end{array}$ & $\begin{array}{l}\text { Long. } \\
\text { C1rcum. }\end{array}$ & $\begin{array}{c}43,000 \\
-\end{array}$ & $\begin{array}{c}68,000 \\
-\end{array}$ & 25 & $\begin{array}{r}18 \\
-\end{array}$ \\
\hline & $\begin{array}{l}\text { Inner } \\
\text { Swaged }\end{array}$ & $\begin{array}{l}\text { Long. } \\
\text { C1rcum. }\end{array}$ & $\begin{array}{c}71,000 \\
-\end{array}$ & $\begin{array}{c}77,000 \\
-\end{array}$ & $\begin{array}{r}14 \\
-\end{array}$ & 32 \\
\hline \multirow[t]{5}{*}{$\begin{array}{l}\text { SPRO-12 and } \\
-13(\mathrm{c})\end{array}$} & $\begin{array}{l}\text { Outer } \\
\text { As-recelved }\end{array}$ & $\begin{array}{l}\text { Long. } \\
\text { Circum. }\end{array}$ & $\begin{array}{l}48,000 \\
48,000\end{array}$ & $\begin{array}{l}76,000 \\
83,000\end{array}$ & $\begin{array}{l}23 \\
16\end{array}$ & $\begin{array}{l}33 \\
44\end{array}$ \\
\hline & $\begin{array}{l}\text { Outer } \\
\text { Swaged }\end{array}$ & $\begin{array}{l}\text { Long. } \\
\text { Circum. }\end{array}$ & $\begin{array}{l}58,000 \\
57,000\end{array}$ & $\begin{array}{l}80,000 \\
90,000\end{array}$ & $\begin{array}{r}10 \\
6\end{array}$ & $\begin{array}{l}18 \\
24\end{array}$ \\
\hline & $\begin{array}{l}\text { Outer } \\
\text { As-rece1ved }\end{array}$ & $\begin{array}{l}\text { Iong. } \\
\text { C1rcum. }\end{array}$ & $\begin{array}{l}45,000 \\
49,000\end{array}$ & $\begin{array}{l}77,000 \\
78,000\end{array}$ & $\begin{array}{l}21 \\
16\end{array}$ & $\begin{array}{l}35 \\
44\end{array}$ \\
\hline & $\begin{array}{l}\text { Outer } \\
\text { vibrated }\end{array}$ & $\begin{array}{l}\text { Long. } \\
\text { C1rcum. }\end{array}$ & $\begin{array}{l}50,000 \\
48,000\end{array}$ & $\begin{array}{l}72,000 \\
78,000\end{array}$ & $\begin{array}{l}24 \\
15\end{array}$ & $\begin{array}{l}35 \\
44\end{array}$ \\
\hline & $\begin{array}{l}\text { Inner } \\
\text { As-recelved }\end{array}$ & $\begin{array}{l}\text { Long. } \\
\text { C1rcum. }\end{array}$ & $\begin{array}{c}45,000 \\
-\end{array}$ & $\begin{array}{c}75,000 \\
-\end{array}$ & 24 & $\begin{array}{r}35 \\
-\end{array}$ \\
\hline
\end{tabular}

(a). Fach value the average of at least three specimens.

(b) Zircaloy-2

(c) Low-N1 Zircaloy-?

As expected, the tensile elongation of the sheath varied inversely with the sheath strength. However, in similar sheathing, the circumierential elongation was always less than the longitudinal elongation, but the reduclion in area in the circumferential direction was always greater than in the longitudinal direction. This behavior indicated that the amount of uniform elongation was less in the circumfertial direction than in the longitudinal direction and that the clrcumferential strain was localized. Furthermore, circumferential specimens necked equally in width and thickness, and longitudinal specimens necked predominantly in width.

Preferred orientation measurements $(8)$ of the tubing. showed that the poles of the basal (0001) planes were predominantly orlented in the circumferential direction. 
The strain behavior described above is consistent with this texture and the slip systems for zirconium observed by Rappaport ${ }^{(\theta)}$.

These tensile properties indicated that the unirradiated sheath was very suitable for reactor service and contained sufficient ductility to accommodate any strain that should occur during Irradiation.

\section{Weld - Shear Tests}

The results of the pre- and postirradiation weld-shear test are given in Table III.

\section{TABLE III}

Weld-Shear Strengths of Inner Sheath Welds

\begin{tabular}{|c|c|c|c|c|c|}
\hline $\begin{array}{l}\text { Assembly } \\
\text { Number }\end{array}$ & $\begin{array}{l}\text { Element } \\
\text { Number }\end{array}$ & Type & Condition & $\begin{array}{l}\text { Weld } \\
\text { Streng }\end{array}$ & $\begin{array}{l}\text { hear } \\
h, \quad 1 b\end{array}$ \\
\hline SPRO-5 & $7-93$ & Swaged & Unirradated & 8900 & \\
\hline & $z-93$ & Swaged & Unirradiated & 8900 & 8300 \\
\hline & $z-96 B$ & Swaged & Unirradiated & 8200 & \\
\hline & $Z-96 B$ & Swaged & Unirradiated & 7300 & \\
\hline & $Z-90 A$ & Swaged & Irradiated & 8100 & 8100 \\
\hline SPRO-12 & $Z-186 A$ & Swaged & Un1rradiated & 5000 & \\
\hline & $z-186 B$ & Swaged & Un1rradiated & 7100 & 6200 \\
\hline & $\angle-178 A$ & Vibrated & Unirradiated & 7100 & \\
\hline & $Z-181 A$ & Vibrated & Unirradiated & 5500 & \\
\hline & $\begin{array}{l}Z-184 A \\
Z-184 A\end{array}$ & $\begin{array}{l}\text { Swaged } \\
\text { Swaged }\end{array}$ & $\begin{array}{l}\text { Irradiated } \\
\text { Irradiated }\end{array}$ & $\left.\begin{array}{l}7500 \\
5600\end{array}\right\}$ & 6600 \\
\hline SPRO-13 & $z-207 C$ & Swaged & Un1rradiated & 6700 & \\
\hline & $Z-211 B$ & V1brated & Un1riadiated & 7600 & \\
\hline & $z-208 c$ & Swaged & UnIrradlated & 7200 & 7600 \\
\hline & $z-207 c$ & Swaged & Unirradiated & 8300 & \\
\hline & $Z-210 B$ & Vibrated & Unirradiated & 8300 & \\
\hline & $\mathrm{Z}-207 \mathrm{~B}$ & Swaged & Irradiated & 7600 & \\
\hline & $Z-207 B$ & Swaged & Irradiated & 8900 & 8500 \\
\hline & $Z-210 D$ & V1brated & Irradlated & $9000)$ & \\
\hline
\end{tabular}

The preirradiation tests revealed that the welds in companion tubes to the SPRO-12 assembly were the weakest, fracturing at the average load of 6200 pounds. The welds in companion tubes to the SPRO-13 assembly fractured at an average load of 7600 pounds, while the SPRO-5 companion tubes had an average weld strength of 8300 pounds.

The differences in weld strength in the SPRO-12 and -13 assemblies were due to differences in welding procedure, rather than weld design or sheath properties. The average weld penetration for the SPRO-12 companion tubes was approximately $26 \mathrm{mils}$ with an average minimum penetration of 23 
mils. The 26-mil penetration was approximately $14 \%$ less than the average inner sheath thickness of 30 mils. Therefore, the average weld strength would have been $14 \%$ higher, 7200 pounds instead of 6200 pounds, if complete penetration had been achieved. Subsequently, the welding power was Increased to achieve an average penetration equal to the sheath thickness in the welds for the SPRO-13 assembly. The average weld strength for the SPRO-13 companion tubes, 7600 pounds, 1s very close to the calculated average strength of 7200 pounds that would have been obtalned in the SPRO-12 assembly if complete penetration had been obtained.

The high weld strength of the SPRO-5 companion tubes was attributed to oxygen and nitrogen contamination of the sheath during the welding operation. Oxygen and nitrogen have been shown $(13)$ to increase the tensile strength of Zlrealoy, and there wa no reason to assume that slullal increases should not occur in weld-shear test.

The welas of the irradiated tubes of the SPRO-13 assembly were significantly stronger than those for the unirradiated companion tubes, showing that irradiation may increase the strength of the welds. There were no statistically significant differences in the pre-and postirradiation strengths of welds from tubes in the SPRO-5 and -12 assemblies.

The stress at weld fallure on the inner sheath of unirradiated SFRO-13 companion tubes averaged 48,000 psi. This value closely approximates the yield strength of longitudinal section of Zircaloy tubing used to fabricate the fuel elements and indicates that the weld-shear stress represents the stress required to cause locallzed yielding in the adjacent sheath. In fact, the welds fractured with almost no macroscopic deformation in the sheath, except in the heat-affected zone.

Th1s lack of ductility should not affect the serviceability of the fuel elemerit, however, because the internal pressure required to produce a stress large enough to cause weld rallure, 4000 psi at room temperature, is far greater than the pressure required to cause element fallure by collapse of the inner sheath, $\sim 1500$ psi at room temperature.

\section{Mechanical Burst Tests}

The irradiation exposures of these assemblies did not noticeably affect the ductility of the outer sheath. The ductility values for most of the irradiated sections were 
nearly equal to those for unirradiated companion sections fabricated in the same manner, as shown in Table IV. The uniform and total clrcumferential elongations show that the vibratory compacted elements were more ductile than the swaged elements, both before and after irradiation.

\section{TABLE IV}

Mechanical Burst Tests of Sheathing

\begin{tabular}{|c|c|c|c|}
\hline $\begin{array}{c}\text { Assembly } \\
\text { Number }\end{array}$ & Condition & $\begin{array}{c}\text { Total } \\
\text { Elongation, } \\
\%\end{array}$ & $\begin{array}{l}\text { Minimum } \\
\text { Elongation, } \\
\text { \% }\end{array}$ \\
\hline \multirow[t]{2}{*}{ SPRO-5 } & Un1rradiated, swaged & $\begin{array}{l}27 \\
26\end{array}$ & $\begin{array}{l}21 \\
20\end{array}$ \\
\hline & Irradiated, swaged & $\begin{array}{l}27 \\
27 \\
18(a) \\
19(a)\end{array}$ & $\begin{array}{l}21 \\
19 \\
13 \\
14\end{array}$ \\
\hline \multirow[t]{4}{*}{ SPRO-12 } & Unirradiated, vibratory & $\begin{array}{l}35 \\
37\end{array}$ & $\begin{array}{l}30 \\
34\end{array}$ \\
\hline & Irradiated, vibratory & $\begin{array}{l}36 \\
20(a)\end{array}$ & $\begin{array}{l}32 \\
17\end{array}$ \\
\hline & Unirradiated, swaged & $\begin{array}{l}27 \\
28\end{array}$ & $\begin{array}{l}20 \\
25\end{array}$ \\
\hline & Irradiated, swaged & $\begin{array}{l}27 \\
15(a) \\
10(a)\end{array}$ & $\begin{array}{r}19 \\
12 \\
9\end{array}$ \\
\hline \multirow[t]{4}{*}{ SPRO-13 } & In1rradiated, vibratory & $\begin{array}{l}36 \\
37 \\
38\end{array}$ & $\begin{array}{l}31 \\
34 \\
32\end{array}$ \\
\hline & Irradiated, vihratory & $\begin{array}{l}36 \\
36 \\
37\end{array}$ & $\begin{array}{l}29 \\
32 \\
27\end{array}$ \\
\hline & Untrradiated, swaged & $\begin{array}{l}27 \\
29\end{array}$ & $\begin{array}{l}21 \\
23\end{array}$ \\
\hline & Irradlated, swaged & $\begin{array}{l}27 \\
30 \\
29\end{array}$ & $\begin{array}{l}24 \\
27 \\
28\end{array}$ \\
\hline
\end{tabular}

(a) Premature fallure due to improper positioning of specimen.

In several tests, fallure of the irradiated sections began prematurely by tearing at the specimen edges. These premature failures were probably caused by improper positioning of the specimen during testing and did not represent an 
effect of irradiation damage, although the possibility exists that irradiation increased the notch sensitivity of the metal and thus contributed to the premature fallures.

The specimens, both irradiated and unirradiated, developed an elliptical shape during deformation because variations in sheath thickness produced higher stresses at the thinner sections and caused the deformation to be localized in these regions.

The mechanical burst tests showed that there was sufficient ductility in the irradiated sheath to withstand sheath strains produced by internal gas pressure buildup and by differential thermal expansion of the oxide core and the sheath.

\section{CONCLUSIONS}

The results of these tests indicate that large diameter tubular elements should not fail by either sheath rupture or weld separation due to irradiation embrittlement. In this event, calculations (14) have shown that the limiting stress should be that stress required to cause sheath collapse. The tests also showed that the irradiation exposures, up to approximately $10^{20}$ fast nvt, had no noticeable effect on the sheath ductility, as measured by mechanical burst tests.

These conclusions would be invalid, however, if severe hydriding, such as was previously observed in the SPRo test series $(1)$, were present. 


\section{REFERENCES}

1. Caskey, G. R., G. R. Cole, and W. G. Holmes. "Fallures of $\mathrm{UO}_{2}$ Fuel Tube by Internal Hydriding of Zircaloy-2 Sheaths", Symposium on Powder Packed Uranium Dioxide Fuel Elements. Jo1nt U. S.-Euratom, CEND-153, Vol. II p. IV-E-1. (1961).

2. Knecht, R. L. and P. J. Pankaskle. Strength and Metallurgical Properties of the Zircaloy-2 Pressure Tubes for the PRTR. Hanford Atom1c Products Operation, R1chland, Wash. USAEC Report HW-73398 (1962).

3. Rittenhouse, P. L. and M. L. P1cklesimer. Metallurgy of Zircaloy-2. Part 1. The Effects of Fabrication Varlables on the Anisotropy of Mechanical Properties. Oak Ridge National Lab., Tenn. USAEC. Report ORNL-2944 (1960).

4. Burton, H. H. Hydrogen Effects of Zircaloy-2 Tensile Properties. Hanford Atomic Products Operation, Richland, Wash. USAEC Report HW-61077 (1959).

5. Green, H. M., et al. A Study of Factors Affecting the Ductility of Tubular Zircaloy-Clad Fuel Elements. Nuclear Metals, Inc., Concord, Mass., USAEC Report NMI-7211 (1962.) .

6. Howe, L. M. and W. R. Thomas. The Effect of Neutron Irradiations on the Tensile Properties of Z1rcaloy-2. Atomic Energy of Canada Ltd., Chalk River, Ont. Report AECL-809 (1959). CRMet-827

7. Klepfer, H. H. and C. N. Spalari. "Mechanical Behavior of Cold Worked Nuclear Grade Z1rcaloy-2 Tubing", Nuclear Metallurgy, Vol. VII, AIME, New York, p.7, (1960).

8. Sturcken, E. F. and W. G. Duke. Measurement of Preferred Orientation of Thin-Walled Zircaloy-2 Tubes. E. I. du Pont de Nemours \& Co., 3avamah River Laboratory, Aiken, 3. C., USAEC Report DP-607 (1961).

9. Rapperport, E. J. "Room Temperature Deformation Processes in Zirconium", Fundamental Research and Development in Metallurgy - Annual Report to the Research Division for the Perlod of July 1957 to June 1958, Nuclear Metals, Inc., Concord, Mado. USAEC Report NMI-1215, pp. 9-10 (1959).

10. Heavy Water Moderated Power Reactors - Progress Report June 1960. E. I. du Pont de Nemours \& Co., Wilm1ngton, Del. USAEC Report DP-515, p. 20 (1960).

11. Ib1d. September 1961. DP-665, p. 11 (1961).

12. Ib1d. February 1962. DP-715, p. 14 (1962).

13. Ib1d. September-October 1963. DP-875, p. 13 (1963).

14. The Metallurgy of Z1rconium. National Nuclear Energy Series VII-4, New York: McGraw-H1ll, pp. 509-17 (1955). 